\title{
Les collectifs de scénaristes ou la « fabrique » du métier
}

Compagnonnage et solidarités dans le travail créatif

Screenwriters' Collectives or the "Making Of" a Profession. Companionship and

Solidarity in Creative Work

Los colectivos de guionistas o la «fábrica» del oficio. Compañerismo y

solidaridades en el trabajo creativo

\section{Anne-Sophie Béliard et Sarah Lécossais}

\section{(2) OpenEdition}

\section{Journals}

Édition électronique

URL : http://journals.openedition.org/bssg/422

DOI : $10.4000 /$ bssg.422

ISSN : 2490-9424

Éditeur

Presses universitaires de Vincennes

Référence électronique

Anne-Sophie Béliard et Sarah Lécossais, « Les collectifs de scénaristes ou la « fabrique » du métier », Biens Symboliques / Symbolic Goods [En ligne], 6 | 2020, mis en ligne le 30 avril 2020, consulté le 04 mars 2021. URL : http://journals.openedition.org/bssg/422 ; DOI : https://doi.org/10.4000/bssg.422 


\section{Les collectifs de scénaristes ou la " fabrique " du métier} Compagnonnage et solidarités
dans le travail créatif

\section{Screenwriters' Collectives or} the "Making Of" a Profession

Companionship and Solidarity in Creative Work

\author{
Anne-Sophie Béliard | Sarah Lécossais \\ traduction | translation \\ Jean-Yves Bart
}

En 1995, dans son ouvrage pionnier sur les scénaristes de fictions TV, Dominique Pasquier souligne la lutte de ces professionnel-le.s pour leur reconnaissance. Les séries, alors marquées en France par une forte illégitimité culturelle, impriment sur leurs auteur.rice-s une forme de discrédit social. La récente évolution de la hiérarchisation des genres télévisuels, passant par une revalorisation de certains formats ${ }^{1}$, invite à se re-pencher sur la profession de scénariste. Les très médiatisées Dix pour cent, Un village français, Le Bureau des légendes laissent entrevoir une possible reconnaissance du travail et du statut de celles et ceux qui les inventent - ou du moins une visibilisation de certain·e.s d'entre elles et eux. Pour éclairer ces évolutions, cet article propose d'étudier un mode de coopération informel récemment développé en France, les collectifs de

1. Cette valorisation est en partie initiée par le succès des séries dramatiques états-uniennes (drama), en particulier les séries HBO, participant de la Quality TV (Edgerton \& Jones 2008 ; McCAbe \& Akass 2007).
In her pioneering book on television screenwriters (1995), Dominique Pasquier described these professionals' struggle for recognition. Television series were at the time utterly lacking in cultural legitimacy, and their authors were socially discredited. Recent developments in the hierarchy of television genres, whereby some formats have been revalued ${ }^{1}$, call for a reassessment of the profession of screenwriter. Series such as Dix pour cent (Call My Agent!), Un village français (A French Village), and Le Bureau des légendes (The Bureau), which have received considerable attention, offer a glimpse of a recognition for the labour of those who invent them-or at least of increased exposure for some of them. To shed light on these trends, this paper examines an informal mode of cooperation that has recently developed in France-screenwriters' collectives-and the ways in which their organization contributes

This newfound appreciation was partly triggered by the success of some US dramas, especially those released by HBO, which have been referred to as Quality TV (Edgerton \& Jones 2008; McCabe \& Akass 2007). 
scénaristes, et la façon dont leur organisation contribue à définir les pratiques et l'identité professionnelle des individus qui y participent.

Les collectifs apparaissent à la fin des années 2000 et regroupent des scénaristes qui échangent des conseils sur leurs projets. Alors que l'activité de scénariste est prise dans des tensions entre des aspirations artistiques et une contrainte économique aboutissant à l'acceptation de commandes " alimentaires ", nous faisons l'hypothèse que les collectifs peuvent réconcilier ces deux aspects. Les professions artistiques sont soumises à des incertitudes sur l'avenir professionnel, la viabilité des projets dans lesquels s'engagent les individus et leurs rétributions monétaires (Freidson 1986), parfois compensées par l'anticipation de contreparties non monétaires (Cardon \& Pilmis 2013). Nous envisageons que l'engagement dans un collectif participe d'une logique de prémunition contre ces incertitudes et de renforcement des possibilités de rétribution. II s'agit dès lors d'explorer la tension individu-collectifgroupe professionnel qui anime l'activité de scénariste, l'allerretour permanent entre des pratiques collectives de coordination et de coopération, et des logiques de positionnement personnel dans un groupe professionnel en quête de reconnaissance. Dans quelle mesure les logiques d'organisation des collectifs de scénaristes contribuent-elles à requalifier les pratiques, les identités et les relations professionnelles mêmes des auteur.rice.s ?

La spécificité de notre analyse tient aux caractéristiques du métier de scénariste et à la nature des regroupements sociaux étudiés. En effet, le caractère informel des collectifs et leurs activités les distinguent, par l'absence de statut légal, de la forme associative et du syndicat professionnel. Le rôle accordé aux collectifs repose donc sur une logique alternative, possiblement complémentaire, au rôle des organisations syndicales dans la structuration des professions artistiques (Grégoire 2009 ; Freidson 1986). En se to defining the practices and professional identity of participating individuals.

Screenwriters' collectives appeared in the late 2000s, with the aim of providing spaces for these professionals to exchange advice on their projects. As the profession of screenwriter is characterized by tension between artistic aspirations and economic pressure, resulting in writers taking on some assignments just to pay the bills, we posit the hypothesis that these collectives are able to reconcile these two aspects of the job. Artistic professions are subject to uncertainties regarding career prospects as well as the viability of the projects to which they commit and their financial rewards (Freidson 1986), which is sometimes alleviated by the anticipation of rewards other than financial (Cardon \& Pilmis 2013). We explore the idea that getting involved in a collective may be part of an effort to fend off such uncertainties and maximize rewards. This requires investigating the tension between individual, collective and professional group at work in this profession-the constant back and forth between collective practices of coordination and cooperation, and personal positioning dynamics in a professional group that is striving for recognition. We consider to what extent the organizational forms of screenwriters' collectives contribute to redefining the practices, identities and the professional relationships of writers.

Our analysis differs from similar studies due to the characteristics of the profession of screenwriter and the nature of the social groupings investigated. Collectives have an informal status, which is not framed by legal provisions. This makes their activities different from those of associations and professional unions. The role granted to collectives draws on a rationale that constitutes an alternative, and possibly a complement, to that of trade unions in the structuring of artistic professions (Grégoire 2009; Freidson 1986). 
constituant comme des groupes publiquement identifiables (par leur nom et la présentation de leurs membres), les collectifs se distinguent également des réseaux personnels. L'analyse des collectifs ne relève donc pas ici d'une étude des effets des réseaux sur les marchés et carrières professionnels via l'analyse des réseaux, mais bien de l'étude d'un mode de collaboration professionnelle spécifique.

Dans cette perspective, notre analyse se situe, d'une part, entre sociologie des professions et sociologie des médias. Elle renvoie aux travaux portant sur les professionnels de l'audiovisuel (Pasquier \& Chalvon-Demersay 1990 ; Pasquier 1995) et les études des groupes et rapports professionnels dans le milieu artistique (Menger 2002 ; Heinich 1993 ; Chiapello 1998). Si les recherches sur le travail dans la culture ont montré le développement de chaînes de coopération (Becker 1988) et le rôle de la commande dans la création (Baxandall 1985), nous plaçons la focale sur le collectif afin d'appréhender les scénaristes par leurs compétences et leurs rapports aux autres professionnel-le·s de la télévision. Cette recherche intègre, d'autre part, les apports des cultural studies en interrogeant les rapports de pouvoir, notamment les rapports sociaux de genre, dans lesquels les scénaristes sont pris·es et en envisageant ces dernier-e.s comme des " créateurs et créatrices de symboles » au cœur des industries culturelles (Hesmondhalgh 2007). Pour ce faire, cet article s'appuie sur une enquête qualitative (en cours) auprès de scénaristes impliqué·e·s dans des collectifs.
As they are formed as publicly identifiable groups (with names and lists of members), collectives also differ from personal networks. Therefore, the analysis of collectives proposed here shall not be part of a study on the effects of networks on professional markets and careers through network analysis; it is the study of a distinct form of professional collaboration.

In this sense, our analysis is on the one hand situated halfway between the sociology of professions and the sociology of the media. It draws on research on audio-visual professionals (Pasquier \& Chalvon-Demersay 1990; Pasquier 1995) and on studies of professional groups and relationships in the art world (Menger 2002; Heinich 1993; Chiapello 1998). Where research on labour in culture has evidenced the development of chains of cooperation (Becker 1982) and the role of commissions in creation (Baxandall 1972), here we focus on collectives to approach screenwriters in terms of competences and relationships to other television professionals. On the other hand, our research also builds on findings in cultural studies, as it questions the power relations, including gendered social relations, in which screenwriters are involved and envisions them as "symbol creators" at the heart of the cultural industries (Hesmondhalgh 2007). To achieve this, this paper draws on an ongoing qualitative study on members of screenwriters' collectives. 


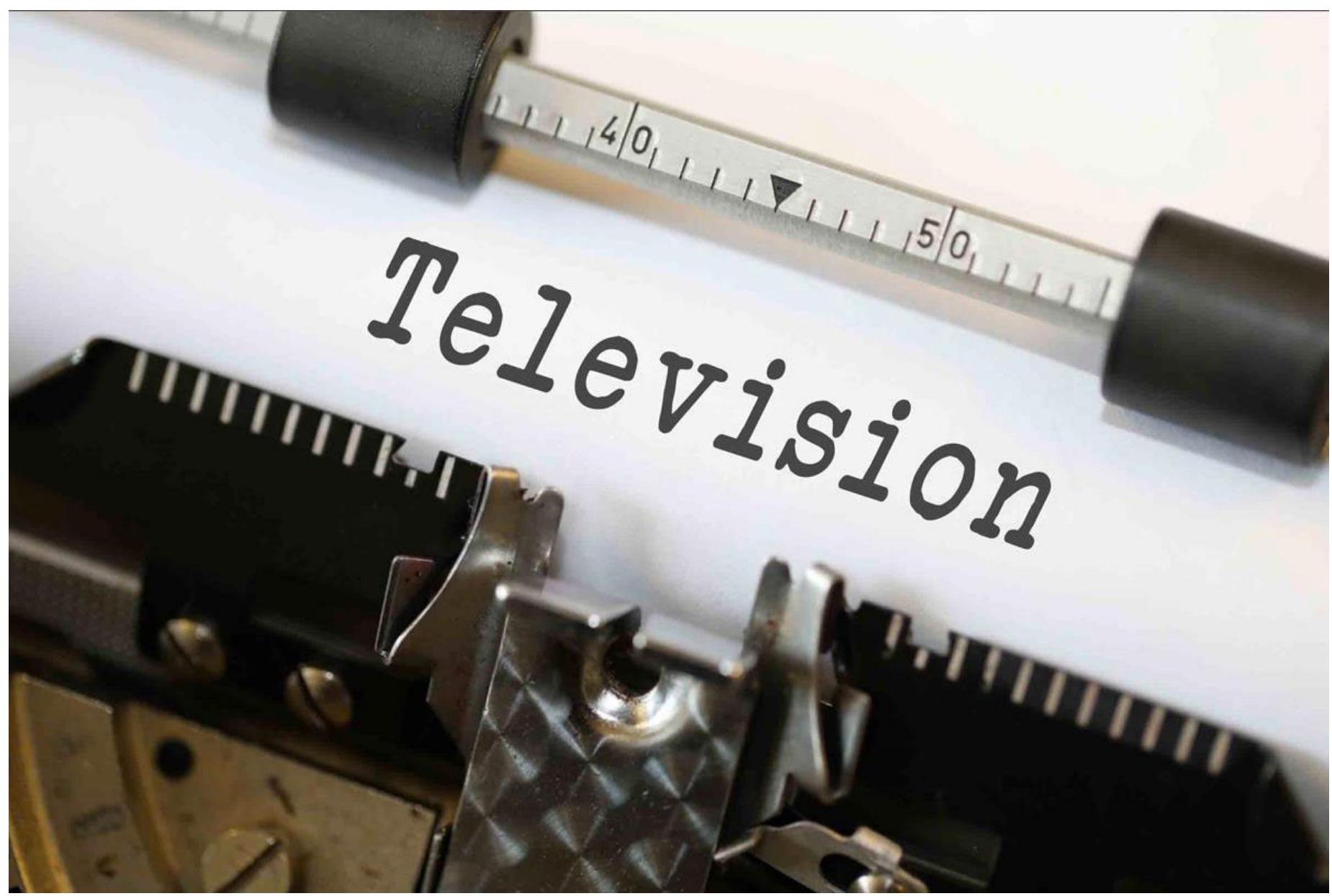

Fig. 1. Écrire pour la télévision ๑ Television, par Nick Yougson. Source : CC BY-SA 3.0 ImageCreator / Writing for Television (๑) Television, by Nick Yougson. Source : CC BY-SA 3.0 ImageCreator. 


\section{Méthodologie}

La recherche est menée principalement par entretiens semidirectifs : vingt-deux scénaristes, entre 25 et 53 ans, perçu $\cdot e \cdot s$ par nous comme blanc.he.s et issu.e.s de cinq collectifs différents ont été interrogé $\cdot e \cdot s^{2}$. Nous avons commencé l'enquête par le premier collectif créé, grâce à un contact membre. Ce point d'entrée explique la surreprésentation actuelle du premier collectif dans nos données (11 enquêté·e.s sur 22), dont une grande majorité des membres écrivent ou ont écrit des séries. L'enquête se déploie progressivement, par réseau d'interconnaissance. Les scénaristes femmes sont majoritaires dans notre enquête (16) bien qu'elles demeurent minoritaires dans leur milieu professionnel. En effet, si leur nombre est en augmentation régulière, elles représentent en $201634 \%$ des effectifs d'auteur.rice-s de fiction $\mathrm{TV}^{3}$. Leur surreprésentation, dans notre enquête, est liée au fait que les collectifs repérés comptent davantage d'hommes qui n'écrivent pas de séries (mais du cinéma ou de l'animation). Toutes habitent et travaillent désormais à Paris : c'est donc d'un milieu très parisien que nous rendons compte $^{4}$. Cet état de fait est lié au marché de l'emploi, les principaux recruteurs étant les sociétés de production, et surtout les grandes chaînes nationales ${ }^{5}$.

2. Les noms des scénaristes et des collectifs ont été anonymisés (cf. tableau 1).

3. Où sont les femmes ? Saison 2015-2016, brochure de la SACD (Société des auteurs et compositeurs dramatiques).

4. En 2011, $81 \%$ des auteur.rice-s de l'audiovisuel résidant en France habitent à Paris. Voir Gouyon $2011: 1-32$.

5. Les nouveaux arrivants sur le marché, tels Amazon et Netflix, commencent à se lancer dans la production de séries en France, par exemple Marseille, Plan cour et, plus récemment, Family Business. Les lieux de rencontre et de négociation demeurent parisiens.

\section{Methodology}

Our research consists mainly of semi-directive interviews with 22 screenwriters from five different collectives, aged between 25 and 53, whom we perceived to be white ${ }^{2}$ We began our study with the oldest of these collectives, having been introduced by a member acquaintance. This introduction to the fieldwork explains the current overrepresentation of this first collective in our data (11 of 22 interviewees). The vast majority of its members write or have written television series. Our investigations have progressed gradually, drawing on networks of acquaintances. Female screenwriters form the majority of our interviewees (16) even though they remain a minority in their professional milieu. While their numbers have been regularly increasing, as of 2016 , women made up 34\% of all television screenwriters ${ }^{3}$. Their overrepresentation in our research relates to the fact that the men in the collectives under study tend not to write series (but films or animation). All currently live and work in Paris; the professional world described in this paper is largely Parisian ${ }^{4}$. This is a result of the state of the job market in the sector: the main employers are production companies and especially prominent national television channels ${ }^{5}$.

2. The names of screenwriters and collectives have been anonymized (see Table 1).

3. "Où sont les femmes? Saison 2015-2016" ("Where are the Women? 2015-2016 season"), brochure edited by the French society of dramatic authors and composers SACD (Société des auteurs et compositeurs dramatiques)

4. In $2011,81 \%$ of authors in the audio-visual sector in France resided in Paris See Gouyon 2011: 1-32.

5. New actors in the market such as Amazon and Netflix have begun producing series in France, with titles including Marseille, Plan coeur and most recently Family Business. The places where screenwriters meet and negotiate are still in Paris; talks about the remuneration of authors (especially since the adoption of the directive on authors' rights in 2019) will be central to the evolution of this market. 
Nous procéderons d'abord à une présentation de l'organisation et du fonctionnement des collectifs avant d'interroger, dans un deuxième temps, le rôle de ces groupes dans les identités professionnelles des scénaristes. Nous montrerons que ces collectifs peuvent être envisagés comme une réponse aux difficultés et contraintes du métier et participent à la promotion d'un vocabulaire commun tout comme de la création de réseaux de solidarité. Enfin, nous discuterons des apports des collectifs pour la conquête individuelle d'autonomie professionnelle de leurs membres.

\section{Les collectifs de scénaristes : principes et} fonctionnement

Nous verrons ici l'émergence et les règles internes des collectifs, dont les membres se réunissent à intervalle régulier, se lisent et se

conseillent.

\section{1. Émergence et développement des collectifs en France}

Nous avons identifié douze collectifs, créés entre 2007 et le milieu des années $2010^{6}$. II n'est cependant pas aisé de dénombrer précisément les collectifs existants et actifs aujourd'hui car une partie d'entre eux ne sont pas publicisés et restent invisibles dans l'espace médiatique. Nous dressons donc le panorama des collectifs volontairement rendus visibles par leurs membres, possédant des « vitrines » publiques (site internet, page Facebook) qui mettent en avant leur fonctionnement et les individus qui les composent ${ }^{7}$

6. Les collectifs ont été identifiés à partir d'une recherche sur le Web et des entretiens réalisés.

7. Les espaces numériques des collectifs proposent une liste, avec photographie, de leurs membres et, dans la plupart des cas, mettent en ligne leurs CV. Les pages d'accueil mettent en avant l'actualité des membres (sélections dans
We begin by presenting the organization and operation of the collectives. We then consider the role played by these groups in the construction of the screenwriters' professional identities. We show that these collectives can be seen as a response to the struggles and constraints of the job, and contribute to the promotion of a shared vocabulary and the creation of networks of solidarity. Lastly, we examine how collectives help their members in their individual pursuits of professional autonomy.

\section{Screenwriters' Collectives: Principles and Operation}

This section focuses on the emergence and internal rules of collectives, whose members meet on a regular basis, read each other's work and give each other advice.

\subsection{The Emergence and Development of Collectives in France}

We have identified twelve collectives created between 2007 and the mid-2010s ${ }^{6}$. However, drawing up a comprehensive, precise list of currently existing and active collectives is no easy task, as some have no publicity and remain invisible in the media. We therefore provide an overview of the collectives that are publicized by their members, and equipped with public displays (websites, Facebook pages, etc.) that contain information about their functioning and membership. ${ }^{7}$

6. Collectives were identified on the basis of a web search and of our interviews 7. The collectives' websites include a list of members with photographs, and in most cases, CVs. Homepages feature news about members (festival selections, awards, funding obtained, television broadcasts of their works, etc.) 
Le premier collectif français a été créé en 2007 , dans un contexte de " crise » de la fiction française. Cette crise est caractérisée par une baisse de l'audience et de la place de la fiction française (rapport du CSA, 2010). Les enjeux d'audience se doublent d'une baisse du volume de la fiction au début des années 2000 à un moment où les séries françaises, plus chères à la production que les séries états-uniennes à l'achat, souffrent de la concurrence venue d'outre-Atlantique. La diffusion des Experts sur TF1 à partir de 2001 à la place du film du dimanche soir marque ainsi un tournant important et va de pair avec une crise de confiance envers les professionnel.le·s. Cette concurrence avec les séries états-uniennes se joue également au niveau du contenu des séries qui accusent le coup d'une « crise éditoriale » : " Le monde et les autres genres ont changé alors que notre fiction n'a pas évolué » (rapport du CSA 2010 : 21). Les productions françaises sont alors critiquées pour leur moindre qualité, critiques qui rejaillissent sur les auteur.rice.s.

Conscient·e.s de ces critiques, des scénaristes en début de carrière fondent ce qu'ils et elles nomment un « collectif ». II s'agit d'un groupe dont les membres se réunissent dans un esprit de compagnonnage et d'entraide, afin de discuter, ensemble, de leurs pratiques d'écriture et de leurs difficultés. À la suite de ce premier collectif, d'autres ont vu le jour, prenant le premier comme référence. En 2010, est ainsi créé un second collectif, décrit comme

la version « junior » du premier.

Une différence importante apparaît cependant dans la logique de constitution des collectifs suivants : si tous se présentent comme des " collectifs de scénaristes ", ils ne sont pas uniquement composés d'auteur-rice's de télévision et regroupent aussi des

des festivals, gain de prix, obtention de financements, diffusions télévisées des œuvres, etc.).
The first French collective was created in 2007 amid a national crisis of television drama characterized by weakening ratings and declining output (CSA report 2010). These trends were particularly concerning at a time when French series, which were more expensive to produce than US series were to purchase, suffered from American competition. In 2001, by replacing its usual Sunday night feature film with episodes of the US series CSI: Crime Scene Investigation, the prominent private television channel TF1 marked a major turning point, reflecting a crisis of trust in French professionals. This competition with US series also played out in terms of content, as French series faced an "editorial crisis": "the world and the other genres have changed, but our drama has not evolved" (CSA report 2010: 21). French productions were then criticized for their lesser quality, and these criticisms evidently affected their authors.

In response to these criticisms, young screenwriters founded what they called a "collective": a group whose members meet in a spirit of companionship and mutual aid to talk about their writing practices and their challenges. This first collective was named as a direct inspiration in the creation of subsequent collectives. The second, which appeared in 2010, was described as a junior version of the former.

However, the collectives differ from one another in one key aspect: while all of them present themselves as "screenwriters' collectives," their membership does not only include television writers. Some of their members write for a variety of media and formats (graphic novels, animation, film, radio, theatre) and others are directors 
scénaristes qui réalisent ou écrivent pour différents supports et formats (bande dessinée, animation, cinéma, radio, théâtre...) ainsi que des réalisateur.rice's ou des monteurs ${ }^{8}$ (cf. Tableau 2).

Précisons enfin que, parmi les groupes repérés, si la plupart sont mixtes, deux sont composés exclusivement d'autrices.

Les membres des collectifs se caractérisent par une forme d'homogénéité sociale. Bon nombre de nos enquêté.e.s ont fait des études longues ( 15 ont bac $+4 /+5$ ) et sont passé $\cdot e \cdot s$ par des classes préparatoires (12/22) qui ne les destinaient pas nécessairement à l'écriture ou la création de séries ${ }^{9}$. À l'exception de deux, nos enquêté.e.s sont diplômé·e.s du supérieur : École normale supérieure ${ }^{10}$, écoles de commerce ou d'ingénieur, Sciences Po, études de langues ou de cinéma et d'audiovisuel à l'université, écoles spécialisées ou BTS ${ }^{11}$ dans l'audiovisuel. Ce niveau d'études peut, en partie, être lié à l'origine sociale, relativement homogène, de nos enquêté $\cdot e \cdot s$ qui sont majoritairement issu.e.s de milieux dotés en capital culturel et scolaire : parents cadres, de professions intellectuelles supérieures (journaliste, dessinateur, psychiatre, médecin,...) ou de classe moyenne (enseignants, libraires). Seulement deux scénaristes viennent d'un milieu populaire et insistent d'ailleurs sur la singularité de cette situation :

8. Nous avons concentré notre intérêt sur les scénaristes écrivant des séries télévisées, qui sont particulièrement présents dans ces groupes.

9. Des formations spécialisées au scénario ont été créées récemment au Conservateur européen d'écriture audiovisuelle (CEEA) et à l'École supérieure des métiers de l'image et du son (Fémis). Seul·e·s les plus jeunes de nos enquêté.e.s y ont eu accès.

10. L'École normale supérieure (ENS) est un établissement d'enseignement supérieur public accessible sur concours et formant des enseignant·e.s et chercheur.e.s.

11. Le Brevet de technicien supérieur (BTS) est un diplôme court se préparant en deux ans après le baccalauréat et destiné plutôt aux lycéen·ne·s ayant suivi des études technologiques ou professionnelles. or editors ${ }^{8}$ (see table 2). It is also worth noting that among the collectives under study here, most are mixed-gender, but two are open exclusively to women.

The members of these collectives are characterized by social homogeneity. Many of our interviewees are highly educated (fifteen have four or more years of higher education under their belt) and have attended preparatory classes for admission into one of the elite French institutions (12/22), which did not necessarily prepare them for writing or creating series ${ }^{9}$. With two exceptions, our interviewees are higher education graduates, from institutions including the ENS ${ }^{10}$, business or engineering schools, institutes of political science, languages, cinema or audio-visual university faculties, specialized schools, or holders of a BTS ${ }^{11}$ in the audiovisual field. These levels of educational attainment may partly relate to our interviewees' fairly homogeneous social backgrounds, as the majority come from families well-endowed in cultural and educational capital, with parents in executive positions, higher intellectual occupations (journalist, designer, psychiatrist, physician, etc.) or middle-class occupations (teachers, booksellers, etc). Only

8. Our research focuses on writers of television series, who are particularly involved in these groups.

9. Specialized screenwriting courses have recently been opened at the European Conservatory of Audio-Visual Writing (CEEA) and the Fémis (French National School of Sound and Image Professions). Only the youngest among our interviewees have had the opportunity to attend them.

10. The École normale supérieure (ENS) is a public higher education institution that trains teachers and researchers. Students are selected by examination.

11. The Brevet de technicien supérieur (BTS) is a short technical certificate in which is taken for two years after completing secondary education. It is geared towards students who have followed technical or vocational tracks. 
«Moi je viens d'un milieu de prolétaires et je suis très, très minoritaire dans mon métier, en fait je n'en connais... je n'en connais pas d'autre, je suis la seule. Enfin si, un autre. Et, enfin, vraiment prolétaire, quoi : les parents au Smic ${ }^{12}$ ou sans emploi. Aucun artiste dans la famille, ni tout ça. » (Olympe, 32 ans, collectif 5 .)

Les conditions d'émergence des différents collectifs reposent sur une logique commune, à savoir une rencontre décisive entre les membres (qui vont devenir les membres fondateurs) et ce principalement dans deux contextes: d'une part au cours de festivals (un festival de scénaristes a ainsi été à l'origine de deux collectifs) ; d'autre part au sein des promotions dans les récentes formations spécialisées (l'« atelier scénario » de la Fémis et le « grand atelier série » du CEEA). Les cadres de sociabilité dans lesquels font connaissance les membres des collectifs contribuent, dans une certaine mesure, à forger une similitude dans l'approche du métier et une conception des séries liée au partage d'une même expérience ou d'une même formation.

\subsection{Le fonctionnement des collectifs}

Les collectifs fonctionnent majoritairement de la même façon, sur le modèle du premier. Les membres se réunissent lors de séances collectives qui peuvent commencer par un tour de table qualifié de « tour des actualités ", permettant à chacun·e de présenter ses projets en cours. Trois types de séances se déclinent : la discussion autour d'un texte, la rencontre avec un·e invité·e ou des

12. Le salaire minimum de croissance (Smic) correspond au salaire horaire minimum légal que le salarié doit percevoir two screenwriters among our interviewees have working-class backgrounds and emphasized how unusual this is:

"I come from a working-class background and I'm very, very much in the minority in my job, actually I don't know... I don't know any others, I'm the only one. Well, no, one other person. And you know, really working class, right, with parents on minimum wage ${ }^{12}$ or unemployed. No artists in the family either." (Olympe, 32 years old, collective 5.)

The collectives emerged in similar conditions - that of a decisive encounter between members (who go on to become the founding members), mainly in one of two settings: first, during a festival (two collectives were created after a screenwriters' festival); second, in a class of one of the recently opened specialized screenwriting courses in France (the atelier scénario at Fémis and the grand atelier série at CEEA). To some extent, the social frameworks in which members meet lead to similarities in their approaches to the job and the conception of series, since they share the same experience and training.

\subsection{How Collectives Work}

Most collectives operate in similar ways, based on the model of the first collective. Meetings often start with a round-table discussion in which members present their ongoing projects. There are three types of meeting: some are held to discuss a text, others to meet a guest, and yet others are less codified (and may include analysis of series, or talks about current events in the field).

12. The French hourly minimum wage is the salaire minimum de croissance (Smic), or "minimum growth wage." 
séances moins codifiées (analyse de séries, discussions autour de

l'actualité du champ, etc.).

La discussion d'un texte, envoyé à l'avance par un membre, est l'activité phare du collectif. Chaque membre présent fait un retour sur le texte, d'abord positif, puis, dans un second temps, critique. Cette règle, qui n'était pas choisie d'emblée dans le collectif 5 , a finalement été adoptée afin de rendre les échanges moins difficiles, notamment pour celui ou celle dont la production est passée au crible. Le groupe fonctionne ainsi par ajustements progressifs. Cette régulation témoigne de la volonté de laisser dominer la bienveillance, ainsi que l'entraide entre les auteur.rice.s qui partagent leurs regards, la diversité de leurs compétences et leurs conseils. Les textes présentés sont généralement des projets dits personnels, c'est-à-dire des textes dont les auteur.rice-s sont à l'initiative. Les scénaristes travaillant sur des séries s'écrivant en ateliers ne font pas ou peu lire les synopsis de leurs épisodes car ils et elles bénéficient déjà, ailleurs, d'un espace partagé de travail et de relecture. En effet, les scénaristes évoquant leur expérience sur des séries de 52 minutes récurrentes (comme Chérif, Nina ou Section de recherche) expliquent discuter de leurs propositions avec les directeur.rice.s de collection, leurs co-auteur.rice.s, etc. Ainsi, contrairement à ce qu'on pourrait supposer, les collectifs de scénaristes fonctionneraient moins comme pépinières de projets communs que comme structures informelles d'accompagnement à

la création individuelle.

Certains collectifs ajoutent à ces sessions des séances de réflexion collective sur le métier ou d'accueil d'un·e invité·e susceptible de les aider dans leur travail d'écriture et de création de leurs personnages dans une visée d'authenticité ou de réalisme. Sont ainsi invité·e.s soit des professionnel·le.s de l'audiovisuel, soit des personnes évoluant dans des milieux qui peuvent être dépeints
Discussion on a text, which a member will have sent in advance, is the main activity of these collectives. Each member in attendance provides feedback on the text, first positive, and subsequently critical. The latter rule was not initially used in collective 5, but ultimately adopted to make exchanges less difficult, especially for those presenting their work. Gradual adjustments in the group's operation are therefore possible. This regulation reflects an effort to foster a friendly atmosphere, and encourage mutual aid between the authors who share their perspectives, diverse skillsets, and advice. The texts presented are generally "personal" projects, meaning that they have been written on their author's initiative. The screenwriters who are working on workshopped series seldom read storylines from these works, as they generally have a space for group work and editing elsewhere. Indeed, the writers on recurring fifty-two-minute shows (such as Chérif, Nina or Section de recherche) discuss their proposals with series directors, co-authors, etc. Thus, contrary to what we might expect, screenwriters' collectives work more as informal support groups for individual creation than as incubators for common projects.

In addition to these meetings, some collectives also hold sessions for group reflection on the profession, or welcome a guest who may help them in the process of writing and creating their characters for the purposes of authenticity or realism. Such guests include professionals in the audio-visual sector or individuals in professions that may be depicted in television series (such as lawyers, forensic 
ou exploités dans les séries (avocat·e·s, légistes, commissaires de police, enseignant.e.s). C'est dans le cadre de ce type de séance que l'une de nous a eu l'occasion de présenter auprès du premier collectif son travail doctoral sur les représentations de la parentalité dans les séries françaises. L'observation participante à cette séance permet de décrire son organisation

"C'est le fondateur du collectif qui mène le déroulement de la séance, me présentant en tant qu'invitée et me cédant la parole. La présentation s'ensuit de questions, réflexions, discussions, parfois animées, sur le contenu de l'intervention ${ }^{13}$. [...] Tout au long de cette partie, Clément, qui est le seul à avoir un ordinateur, prend des notes. II fera ensuite le compte rendu de la séance, qu'il transmettra aux autres membres du collectif. Ce premier temps occupe environ deux heures et laisse ensuite la place à un repas commun. Celui-ci a été préparé par deux membres, d'ailleurs croisées dans un supermarché voisin juste avant la séance. $\mathrm{Si}$ des bouteilles sont disposées sur la table pendant la séquence de discussion, le repas vient ensuite. Les treize membres présents sont disposés en cercle, sur le canapé, les fauteuils et chaises regroupés dans le salon pour l'occasion. Une fois le temps d'échange "formel" autour de l'invitée terminé, nous avons donc ensuite bu et mangé, des petits îlots de conversation émergeant au gré des connivences et en fonction des voisin.e.s de chacun et chacune. Cette partie de la soirée a une tonalité beaucoup plus conviviale et on sent bien l'amitié qui relie les membres du groupe. Le retour de la compagne de l'organisateur annonce la fin de la séance. » (Journal de terrain, 15/03/2016.)

13. Nous n'entrons ici volontairement pas dans le détail de ces échanges quil feront l'objet d'une réflexion à un autre niveau. pathologists, police superintendents, or teachers). During one such meeting organized by the first collective, one of the authors of this paper was invited to discuss her doctoral research on representations of parenthood in French series. Her participant observation enabled her to describe the proceedings in detail:

"The collective's founder moderates the meeting. He introduces me as a guest and gives me the floor. The presentation is followed by questions, thoughts, discussions on my presentation-occasionally lively ones ${ }^{13}[\ldots]$ Throughout that part of the meeting, Clément, who is the only one with a computer, takes notes. He will then draw up the minutes of the meeting, and forward them to the collective's other members. This first part lasts around two hours, and is followed by a communal dinner, prepared by two members, who I ran into in a neighbouring supermarket before the meeting. Bottles have been laid out on the table before the discussion, but dinner comes after. The thirteen attending members sit in a circle, on the sofa, chairs and seats that have been gathered in the lounge for the occasion. Once the period of 'formal' discussion of the guest's presentation was over, we thus ate and drank, and small pockets of conversation emerged between acquaintances and neighbours. This part of the evening has a much more congenial atmosphere, and the friendship between the group's members is palpable. The return of the moderator's partner signals the end of the meeting." (Field notes, 15/03/2016.)
13. We have chosen not to elaborate on these exchanges here; they will be analysed at a different level. 
Le mode de gestion du collectif demeure collégial, bien que la cohésion du groupe semble reposer sur les figures des fondateurs du groupe. Les tâches sont prises en charge en alternance d'une réunion à l'autre, afin que l'hôte-sse (généralement la personne ayant l'appartement le plus grand et le plus central dans Paris) n'ait pas la charge mentale constante de l'organisation des séances. Se pose, dans certains groupes, la question de la présidence ou d'une forme de leadership. Ainsi a été mise en place dans le collectif 5 , suite à la tenue d'états généraux et de votes, une " présidence tournante " chaque mois, permettant une meilleure répartition du travail organisationnel et conférant une forme d'horizontalité à la gouvernance, conforme à l'idée de compagnonnage mise en avant par les collectifs. Chaque membre est successivement chargé de la préparation d'une séance et de toutes les tâches afférentes: choix de l'intervenante ou du texte à lire, choix de la date et du

lieu, mails de rappels, communication des documents, etc.

Bien que les collectifs ne soient pas, hormis le 5, des lieux de création de projet ${ }^{14}$, leur mode de fonctionnement et de gouvernance implique un coût pour leurs membres, notamment en temps. Le collectif le plus ancien a désormais douze ans et, entre temps, les configurations familiales des membres ont évolué : sur les douze rencontré·e.s auprès du premier collectifs, deux scénaristes étaient enceintes au moment de l'entretien, et un autre attendait la naissance imminente de son premier enfant. L'une des scénaristes du groupe nous explique ainsi :

\section{« On est très pris. D'ailleurs, là, on vient de passer à une}

14. Le collectif 5 , composé de cinq autrices, est le seul collectif d'écriture qui fonctionne comme pépinière de projets, car les membres se retrouvent pour écrire ensemble, en répondant, par exemple à des appels d'offres. Pour autant, les autrices ne travaillent pas uniquement dans ce cadre, et les projets développés au sein du collectif semblent minoritaires et n'occuper qu'une part de leur activité en tant que scénaristes.
The collective is managed collegially, although group cohesion appears to rest largely on the founders. Members rotate in assuming organizational duties from one meeting to the next, so that the host (generally the person with the biggest and most centrally located apartment in Paris) does not always have to handle the organization of meetings. In some collectives, the question of presidency or a form of leadership has been raised. Thus, in collective 5, after a general assembly was held and votes counted, a "rotating presidency" was introduced on a monthly basis to ensure a better division of organizational labour, conferring on the group a form of horizontal governance that reflects the idea of companionship highlighted by the collectives. Each member is successively entrusted with the preparation of a meeting and all related tasks: choosing the guest or the text submitted for discussion, picking the date and venue, sending out email reminders, documents, and so on.

While, with the exception of number 5 , the screenwriters' collectives are not arenas in which projects are created ${ }^{14}$, their functioning and governance entails costs for members, especially in terms of time. The oldest collective is now twelve years old, and during this time, the family situations of its members have changed: among the twelve we met, two screenwriters were pregnant at the time of our interview, and another was expecting her first child's birth imminently. As one of the members explains:

14. Collective 5, which is composed of five female authors, is the only writing collective that operates as a project incubator, as its members meet to write together, sometimes in response to calls for projects. However, they do not only work within that framework, and the projects they develop within the collective appear to be only a small part of their activity as screenwriters. 
formule toutes les trois semaines parce que tous les quinze jours on y arrivait plus : c'était trop, avec tous les bébés qui sont arrivés. Une crèche ! [rires] [...] C'est vrai que c'est un peu dur de maintenir le rythme [...]. En plus, c'est vrai que, quand on bosse dans la journée, la tête est prise, on rentre le soir c'est "ouin ouin couches-culottes" : après, repartir à réfléchir le soir, pendant deux heures, c'est pas évident, faut être bien motivé, donc voilà. Faut quand mettre être... Mais bon, c'est toujours un plaisir. » (Christine, 53 ans, collectif 1. )

L'ensemble des enquêté $e \cdot s$ souligne l'ampleur de l'investissement temporel que nécessite la participation à un collectif. Au fur et à mesure de l'avancement des carrières - allant de pair avec davantage de responsabilités - et des trajectoires personnelles - naissance des enfants, notamment -, les scénaristes sont confronté $\cdot e \cdot s$ à des problèmes d'emploi du temps. La préparation des séances devient alors contraignante et les individus peuvent choisir de réduire leur investissement, individuellement ou collectivement. Les membres des deux premiers collectifs ont ainsi décidé, ensemble, de diminuer la fréquence des réunions, d'une tous les quinze jours à une toutes les trois semaines, pour répondre aux contraintes individuelles de chacun'e. Le maintien de l'engagement dans le collectif, malgré ces coûts, repose sur l'anticipation ou l'attente de contreparties compensatoires. C'est alors dans la dimension de formation et d'entraide du collectif qu'on peut identifier une des justifications de l'investissement consenti

par les individus.
"We're very busy. Actually, we've just switched to meeting every three weeks, because we couldn't do every two weeks anymore, it was too much, with all the babies that have come in, a real nursery! [laughs] [...] It really is a bit tough keeping up the pace [...]. Also, you know, when you work during the day, you have that keeping your mind busy, you come back home to crying babies and changing nappies, so getting back to thinking about things in the evening, for two hours, it's not easy, you have to be really driven, so, there's that. You have to... But still, it's always a pleasure." (Christine, 53 years old, collective 1 .)

All of our interviewees noted how time-consuming being part of a collective is. As careers progress-usually meaning greater responsibility-and personal trajectories unfold-childbirth being one of their milestones-screenwriters face scheduling issues. Preparing meetings becomes a constraint, and some may choose to reduce their involvement, individually or collectively. For instance, the members of the first two collectives have collectively decided to hold fewer meetings, from every two weeks to every three weeks, so as to take into consideration the members' individual limitations. Despite these costs, continued involvement in the collective draws on the anticipation or expectation of compensation. One form of compensation lies in the collective's contribution to the training of its members and the mutual aid network it offers. 


\section{Le collectif au cœur des nouvelles identités professionnelles}

La participation aux collectifs apparaît comme un support, qui peut être compris comme une réponse à l'isolement et l'individualisme qui caractérisaient le métier (Pasquier 1995). La création des collectifs est une manière de configurer autrement la profession, en se centrant sur les auteur.rice-s et en créant de nouvelles formes de solidarité (Banks \& Hesmondhalgh 2016).

\subsection{Un renfort face aux épreuves et activités sous} contraintes

L'écriture de séries est une création sous contraintes, ce qui implique, pour les scénaristes, un certain nombre de difficultés. C'est, d'abord, une activité marquée par l'isolement : le/la scénariste écrit souvent seul·e, à domicile, dans des conditions matérielles d'écriture parfois difficiles. II n'existe pas en France, dans les chaînes ou les sociétés de production, de writing room comme aux États-Unis. Les scénaristes n'ont donc pas de bureau et, pour pallier ces difficultés, certain·e.s louent des bureaux ensemble.

Les contraintes d'écriture sont aussi très présentes mais, intégrées par les auteur.rice-s, elles ne sont pas forcément synonymes de perte d'autonomie (Mille 2018). Néanmoins le cadre de l'industrie télévisuelle ajoute l'épreuve de la dévalorisation de certaines des séries sur lesquelles ils/elles sont amené·e.s à travailler. À leurs débuts, les scénaristes travaillent sur des séries existantes pour lesquelles il faut accepter la «bible » déjà en place qui tend à réifier les caractères des personnages (Chalvon-Demersay 2011). Ils/elles participent donc à des « commandes », en opposition aux créations qu'ils/elles proposent une fois installé.e.s dans le milieu. Pour autant, l'intégration au collectif encourage le développement de projets personnels, puisque ce sont bien ceux-ci qui sont

\section{The Collective as a Key Locus for the Actualization of New Professional Identities}

Participation in collectives can be understood as a response to the isolation and individualism that used to characterize the profession of screenwriter (Pasquier 1995). The creation of collectives has been a means to reconfigure the profession, by focusing on authors and fostering new forms of solidarity (Banks \& Hesmondhalgh 2016)

\subsection{A Support System in the Face of Professional Trials and Challenges}

Screenwriting for series is creative work that is characterized by a number of limitations, which can be challenging for writers in a number of ways. First, it is lonely work: the screenwriter often works alone, from home, in sometimes difficult material conditions. In France, television channels and production companies do not have the writing rooms of their US counterparts. Therefore, screenwriters have no office, and some choose to remedy this by renting offices together.

Writing constraints are also very much present, but having been internalized by the authors, they do not necessarily entail a loss of autonomy (Mille 2018). However, television industry rules sometimes further devalue some of the series on which writers work. When they begin their career, screenwriters work on existing series and have to accept the relevant "bible" that tends to reify the characters' personalities (Chalvon-Demersay 2011). In doing so, they are working on "commission," as opposed to the creations they may pitch once they have established a foothold in the profession. However, coming up with personal projects is encouraged by membership in a collective, as those projects are the ones discussed in meetings. Most importantly, the sharing of skills 
travaillés lors des réunions. Surtout, le partage de compétences et les retours bienveillants qui sont au cœur du dispositif ont, selon les scénaristes, un effet bénéfique en termes de formation.

\subsection{Se former entre soi : le collectif, espace d'outillage et de partage de compétences}

C'est effectivement au niveau de l'expérience et des compétences que se joue le rôle du collectif. Les créateur.ice.s du premier collectif en viennent à penser qu'en se regroupant, ils et elles pourraient partager leurs connaissances, échanger des méthodes, se forger des outils pour écrire des scénarios de meilleure facture, plus originaux, et faire ainsi évoluer la qualité de la fiction française. L'objectif est bien dans la transmission et le partage, dans la mise " en commun pour s'améliorer " (Bastien, 36 ans, collectif 1). L'initiative du collectif viendrait alors compenser l'absence de formations officielles - pour celles et ceux qui n'ont pu en bénéficier en s'inscrivant dans une logique de développement d'autres « indices réputationnels » (Menger $1991: 69)$, des compétences, de la réputation et de la professionnalisation de l'activité. C'est la volonté de se regrouper pour être plus fort - à la fois en tant qu'individu progressant dans sa pratique professionnelle et en tant qu'individu pris dans un collectif lui permettant de faire front dans son milieu - qui est le moteur de la constitution de ces groupes. Les scénaristes rencontré.e.s soulignent cette double facette du

collectif :

"L'idée, c'était d'être moins seul. Et d'échanger [...], c'était d'avoir un retour un peu de connaisseur sur ce qu'on écrivait. Et aussi de se fédérer, de se remonter le moral, de créer un réseau, un réseau en commun, pour ceux qui commençaient à avoir des touches professionnelles, de pouvoir mettre les autres sur des coups, enfin c'était un peu d'échanger... d'être plus forts en groupe, quoi. " (Esther, 37 ans, collectif 2.) and the constructive feedback that are key features of collective work have beneficial effects in terms of training, according to the screenwriters themselves.

\subsection{In-Group Training: The Collective as a Venue for Acquiring Tools and Sharing Skills}

The main role of the collective is to work on skills and experience. The founders of the first collective came to think that together, they would be able to share knowledge, exchange methods and develop tools to write better, more original scripts and in doing so improve the quality of French drama. This was about transmitting, sharing experiences; "pooling resources to improve them" [Bastien, 36 years old, collective 1]. The collective's initiative is in that sense described as making up for the lack of official training - for those who were unable to attend courses-by developing other "reputational signals" (Menger 1991: 69), skills, reputation, and professionalization. The driving force behind the creation of the collectives was the idea of teaming up to become stronger-both as individuals progressing in their professional practice and as individual parts of a group allowing them to form a common front in their working environment. The screenwriters we met highlighted these two facets of the collective:

"The idea was to be less alone. And to share what we were writing $[\ldots]$ it was to have sort of informed feedback about what we were writing. And also, to join forces, to raise each other's spirits, to create a network, a shared network, for those who started to have professional contacts, they could hook others up. It was kind of exchanging ... being stronger as a group, right." (Esther, 37 years old, collective 2.) 
Être membre d'un collectif offre plusieurs avantages pour la pratique de l'écriture : engranger des techniques, se forger des outils, partager ses savoir-faire et apprendre des autres, bénéficier de retours sur les projets personnels. L'écriture se travaille donc à la fois individuellement et dans le collectif par l'apprentissage continu et l'acquisition d'outils servant le travail créatif.

Lepartage d'outils et de compétencess'articule avec la revendication d'affinités amicales entre membres. Si ces auteur.rice-s travaillent bien ensemble et peuvent mettre à profit les conseils des autres, c'est en partie lié, selon elles et eux, au fait qu'ils et elles " s'entendent bien ". Ces affinités peuvent trouver une explication dans la proximité sociale des membres qui, nous l'avons vu, présentent une forme d'homogénéité. Elle est renforcée par les principes de recrutement des nouveaux membres : les membres en place intègrent des scénaristes qu'ils et elles connaissent. Suite à une discussion collective, les nouveaux membres sont recrutés par recommandation ou cooptation. Sont alors souvent intégrées des personnes ayant suivi les mêmes formations et partageant les mêmes codes d'écriture et de travail. Les collectifs s'organisent en définitive autour de personnes se décrivant comme des «ami·e·s ", proches par l'âge, le niveau de diplômes et l'appartenance sociale. On peut y voir une logique d'homophilie caractéristique de la structure des relations amicales (Bidart 1997 ; Héran 1990). I s'agit donc de se former et de s'outiller dans un « entre-soi » socioculturellement homogène.

\subsection{Les collectifs ou la consécration d'un « nous»} contre « eux»

La mise en place des collectifs semble d'ailleurs aller de pair avec l'affirmation d'une identité professionnelle liée à la capacité - tout autant qu'au goût - du travail collectif. Se met alors en place, dans le discours des scénaristes rencontré·e $\cdot s$, une frontière symbolique
Being a member of a collective has several benefits for writing: learning techniques, developing tools, sharing know-how, and learning from others, as well as getting feedback on personal projects. It turns writing into both individual and collective work, the latter drawing on lifelong training and the acquisition of creative tools.

Members of collectives are also prone to sharing tools and knowledge because they have friendly relationships. These authors work well together and may fruitfully learn from each other's advice partly because in their own words, they "get along well". These affinities are to some extent explained by social proximity among members, who as mentioned earlier are characterized by a significant degree of social homogeneity. These are reinforced by the principles of recruitment of other members, acquaintances, or friends who are recommended or co-opted after a group discussion. The new members are often individuals who have followed the same training and share the same codes for writing and working. Ultimately, collectives are organized around people who describe each other as "friends," and who are close in terms of age, educational attainment and social background. This may reflect a rationale of homophily that is characteristic of the structure of friendly relationships (Bidart 1997 ; Héran 1990). These screenwriters train each other and give each other tools in a socio-culturally homogeneous, tight-knit environment.

\section{3. "Us" versus "Them"}

The development of collectives appears to have gone hand in hand with the affirmation of a professional identity that is bound with the ability to work collectively-as well as the taste for it. In their discourse, the screenwriters we met erected a symbolic border 
entre deux types de professionnel.le·s, via la distinction entre un « eux » et un « nous ». Alors que les scénaristes jusqu'ici étudié·e·s accordaient, dans leurs propos, peu d'importance à l'apprentissage de l'écriture (Pasquier 1995), celles et ceux que nous rencontrons sont au contraire très conscient $\cdot e \cdot s$ de ces enjeux et la formation, tout au long de la carrière, apparaît centrale. Le fait d'être en " apprentissage permanent » (Olympe), de s'entraîner, de se documenter, d'écrire et réécrire, d'être des « laborieux » (Antoine) revient dans les entretiens et témoigne de la volonté partagée d'être performant.e.s, de « faire du bon travail » (Olympe). La formation joue aussi bien au niveau technique que symbolique, sur les manières de faire comme sur les manières d'être (Sofio 2007). Cette quête d'amélioration traduit, pour les fondateur·ice-s du premier collectif, une nouvelle approche du métier. Récemment entré.e.s dans le milieu de la télévision, ils et elles fondent ce collectif en réaction aux postures des scénaristes déjà établi.e.s entendues lors de l'édition 2007 du Festival d'Aix :

« Les tables rondes et les rencontres, c'était naze. C'était pourri, quoi, un grand amphi où ça débitait des banalités, des scénaristes dans la salle se levaient pour dire, en substance : "Moi, j'ai des super projets dans mes tiroirs mais les distributeurs n'ont pas de couilles, personne me commande rien, etc." [...] Or, moi, je ne me sentais pas du tout comme ça. Moi, je me sentais nul, je veux dire, je me sentais, j'étais débutant, on avait tout à apprendre, donc j'avais un peu de... d'espoir d'y arriver et d'ambition, mais je ne trouvais pas que les gens autour de moi étaient supe forts non plus, quoi [...] à part Krivine [...]. Du coup, je disais : "Voilà, je comprends pas : si on ne sait pas balayer devant notre porte, euh... plutôt que de se plaindre des producteurs, des distributeurs et tout, [...] je sens bien que j'ai beaucoup de choses à apprendre, donc il faudrait se réunir pour parler de ça, et que de ça.” » (Clément, 37 ans, collectif 1. ) between two types of professional-an "us" versus"them" distinction. Whereas previously studied screenwriters seldom talked about the importance of learning writing (Pasquier 1995), those we met were by contrast very aware of this issue, and attributed a central place to lifelong training. Terms such as "learning constantly" (Olympe), training, gathering materials, writing, rewriting, "labouring" (Antoine) recur in interviews, reflecting a shared effort to be effective and to "do good work" (Olympe). Training is both a technical and a symbolic necessity, and pertains both to ways of doing and ways of being (Sofio 2007). For the founders of the first collective, this quest for self-improvement reflects a new approach to the job. These newcomers in the world of television created their collective as a reaction to the postures of already established screenwriters heard during the 2007 edition of a Festival in Aix:

"The round tables and meetings stank. It was bullshit, right, this big amphitheatre where people would just blurt out banalities, there were screenwriters in the room who got up to say stuff like: 'I've got great projects in the pipeline, but the distributors have no balls, nobody asks me for anything' [...] The thing is, I didn't feel that way at all. I felt like I was crap, I mean, I felt I was a beginner, we had everything to learn, so I had a little bit... of hope that I would make it and ambition, but I didn't think that the people around me were all that great either, right [...] except for Krivine [...] so, l'd go, well, I don't understand, if we can't keep our own houses in order, umm... instead of griping about producers, distributors and all that $[. .$.$] I can feel that I have a lot to learn, so we should$ meet up to talk about that, and about that only." (Clément, 37 years old, collective 1 .) 
L'objectif du collectif est de prendre le contre-pied de la parole dominante des scénaristes qui se plaignent du pouvoir coercitif des chaînes. Les créateur.ice-s du collectif affichent l'ambition d'améliorer le niveau d'écriture des séries et de réaffirmer l'identité de scénariste en assumant les lacunes dans leur expérience. I y a donc une construction, à la fois individuelle et commune, du métier à l'œuvre dans les collectifs, ce qu'explique Bastien : «On a fabriqué notre métier aussi grâce au collectif, et notre statut grâce au collectif, c'est une manière de travailler grâce au collectif, d'avoir du travail grâce au collectif [...]. » L'idée de « fabrique » du métier illustre la création d'une identité et d'un statut professionnels revendiqués comme siens, dans un souci sous-jacent de distinction par rapport aux formes antérieures du métier de scénariste.

Le collectif 1 est donc créé pour pallier des limites individuelles, mais les discours laissent entrevoir un conflit dans la façon d'aborder l'activité d'écriture. Conflit clairement exprimé par un fondateur qui décrit la création du collectif comme une rupture avec les « vieux de la vieille » (Jérôme, 41 ans). Une frontière se dessine ainsi avec l'émergence d'un « eux » et d'un « nous ", les premier.e.s ayant connu l'âge d'or des séries policières de 90 minutes de la décennie 1990 et restant sur leurs acquis, tandis que les second.e.s ont été "biberonné·e·s " (selon plusieurs enquêté·e·s) aux séries étatsuniennes, ont fait leurs armes sur des séries de 52 minutes, en ateliers, et désirent s'améliorer.

\subsection{Le collectif, réponse à l'individualisme dans le travai} créatif ?

Cette opposition reflète une tension entre une réponse individualiste et une réponse collective à la concurrence du milieu des scénaristes. Nos enquêté·e.s insistent en effet sur l'évolution
The collective took a stand against the dominant discourse of screenwriters, who complained about the coercive power of television channels. Its creators stated their ambition to improve writing standards on series and reassert the screenwriter's identity while recognizing the gaps in their experience. There is, indeed, a construction, both individual and common, of the profession at work in collectives, as Bastien explains: "We've made our job thanks to the collective, too, and our status thanks to the collective, it's a way of working thanks to the collective, of having work thanks to the collective [...]." The idea of "making" [in French fabriquer, literally manufacturing] one's work illustrates the creation of a selfproclaimed identity and status, as part of an effort of distinction from previous forms taken by the profession.

While collective 1 was created to overcome individual shortcomings, the dialogues provide a glimpse into a conflict relating to approaches to writing. This conflict is clearly expressed by a founder, who describes the creation of the collective as a split from the "oldtimers" (Jérôme, 41 years old). A line is drawn between "them" and "us" here; the former have lived through the golden age of the ninety-minute crime series of the 1990s and are accused of resting on their laurels, whereas the latter grew up on a diet of US shows, started out working in writers' pool workshops on fifty-two-minute series, and are eager to get better at their craft.

\subsection{The Collective as a Response to Individualism in Creative Work?}

This opposition reflects a tension between an individualistic response and a collective response to competition in the profession. Our interviews readily pointed to an ongoing shift towards collaborative 
vers une logique collaborative qui permet de pallier collectivement les risques et l'incertitude de leur métier.

« C'est la nouvelle génération de scénaristes. Ils sont beaucoup dans la collaboration, ce sont des gens qui ont un ego vraiment très bien placé dans le travail et pas dans... donc, ça fonctionne. Et ils ont vraiment un amour de la série qui passe avant l'amour d'eux-mêmes et de leur difficulté ou de leur reconnaissance [...]. Je trouve que les scénaristes de cette génération-là, par rapport à la précédente, sont dans la collaboration et le collectif de façon très impressionante. » (Florence, 46 ans, collectif 1.)

Cette posture porte une forme de dénonciation des pratiques précédentes, pensées comme individualistes, qui privilégieraient les intérêts personnels par des négociations individuelles aboutissant à un milieu fragmenté, caractérisé par la prédominance de certain·e·s scénaristes installé·e·s sur le long terme sur une série au détriment des intérêts communs du milieu. Antoine dit d'ailleurs avoir choisi d'intégrer le collectif par rejet de l'individualisme : « Et ça, ça m’intéressait, parce que j'ai toujours été plus quelqu'un qui travaille en équipe et qui joue en équipe qu'un individualiste. ” Les collectifs apporteraient, selon nos enquêté·e·s, une défense collective du statut de scénariste. Ils peuvent alors aussi être entendus comme venant appuyer ou relayer, à un niveau plus global, les revendications de la profession, notamment à la Guilde des scénaristes ${ }^{15}$ au sein de laquelle 15 de nos enquêté·e·s sont

investi·e.s.

La dimension anti-individualiste du collectif trouve son importance dans un contexte de danger financier et d'incertitude élevés quant

15. Née en 2010 , la Guilde des scénaristes est le seul syndicat professionne de scénaristes en France à l'heure actuelle. working methods, designed to collectively address the risks and uncertainty weighing on their jobs.

"It's the new generation of screenwriters. So, they're doing a lot of collaboration, these are people who have a very well-placed ego, it's really placed in the work and not... so it works out. And they really have a love for the series that comes before their love of themselves and their struggles or their recognition [...]. Compared with the previous one, I think the extent to which this generation of screenwriters is into collaboration and collective work is impressive." (Florence, 46 years old, collective 1.)

This posture involves a form of denunciation of previous practices, considered to be individualistic and favouring personal interest through the recourse to individual negotiation, leading to a fragmented profession characterized by the long-term dominance of a few screenwriters working on a single show to the detriment of the profession's collective interests. Antoine claims to have chosen to join the collective out of a rejection of individualism: "I was interested in that, because l've always been more of a person who works in a team, a team player rather than an individualist". According to our interviewees, collectives enable a collective defence of the screenwriter's status. They can also be seen as supports or relays, at a broader level, for the demands of the profession, particularly at the French screenwriters' guild ${ }^{15}$, in which fifteen of our interviewees are active.

The anti-individualistic dimension of collectives resonates in a context of heightened financial risk and uncertainty as to the quality

15. The French screenwriters' guild, the Guilde des scénaristes, was founded in 2010 and remains the country's only screenwriters' trade union to this day. 
à la qualité d'écriture, où les employeurs usent de stratégies de réduction de risques en recrutant des contacts personnels et de confiance (Wreyford 2015 : 88). Or, Nathalie Wreyford montre que l'appui sur l'homophilie, les discours vantant le talent et le mérite, ainsi que la référence à des femmes visibles dans la profession comme preuve de leur juste présence dans les industries culturelles et créatives, tendent à exercer des biais de recrutement défavorables aux femmes - sous couvert de discours critiquant le sexisme. Et, en effet, la plupart des enquêté e.s ne considèrent pas leur monde professionnel comme sexiste. La tension que l'on retrouve donc ici traverse le milieu de la production audiovisuelle et peut être un facteur explicatif de la forte présence des femmes dans les collectifs, voire de l'existence de deux collectifs exclusivement féminins. Elles pourraient y trouver à la fois des espaces bienveillants pour leur pratique d'écriture et compenser le biais de recrutement genré qui s'exprime implicitement dans leur profession.

\section{Les collectifs, tremplins d'autonomisation et de} reconnaissance professionnelle

Loin du mythe du génie solitaire qui a longtemps marqué les représentations des artistes (Heinich 1993), nos enquêté.e.s sont inséré e-s dans des relations sociales qui cadrent leur activité. Le collectif aide à gagner en autonomie et en pouvoir dans ces

relations.

3.1. Le scénariste et son milieu : hiérarchies et rapports de pouvoir

Le processus de création est contraint, à différents niveaux. Les producteur-rice-s détiennent un pouvoir économique et décisionnel. Certain·e·s scénaristes racontent avoir été "virés » du jour au of writing, leading employers to resort to risk reduction strategies consisting in hiring trusted personal contacts (Wreyford 2015: 88). However, Nathalie Wreyford has shown that reliance on homophily, discourse praising talent and merit, and references to visible women in the profession as evidence of their fair representation in the cultural and creative industries tend to foster recruitment biases against women-under the guise of anti-sexist discourse. Indeed, most interviewees do not consider their professional milieu to be sexist. This tension runs across the entire audio-visual production sector and may go some way towards explaining the strong presence of women in collectives, and perhaps the existence of two exclusively female collectives. Arguably, they find in them inclusive spaces for writing and ways to make up for the gendered recruitment bias that is implicitly at work in their profession.

\section{Collectives as Springboards for Autonomization and Professional Recognition}

Far from the myth of the solitary genius that has long prevailed in representations of artists (Heinich 1993), our interviewees are embedded in social relationships that frame their activity. The collective helps them accrue autonomy and power in these relationships.

\subsection{Screenwriters and Their Milieu: Hierarchies and Power Relations}

The creative process involves constraints at a variety of levels. Producers hold the economic and executive power. Some screenwriters say they have been "fired" from a series overnight, 
lendemain d'une série, ce qui a des implications économiques importantes dans une profession où l'assurance chômage n'existe pas, les auteur.rice's n'ayant pas le statut d'intermittent.e.s du spectacle. Les scénaristes sont donc dépendant.e.s professionnellement et économiquement des producteur.rice-s. On retrouve, dans le milieu télévisuel, l'imbrication entre économie et création existant dans le domaine artistique (Menger 2002)

La relation aux réalisateur.rice-s est marquée par la perte de pouvoir artistique du ou de la scénariste une fois le scénario achevé. Même lorsqu'ils et elles ont accès aux plateaux, les scénaristes peinent à trouver leur place sur un tournage car, comme l'indique Margaux (44 ans, collectif 1), aucun espace ne leur est physiquement attribué, ce qui leur donne l'impression de "gêner " en permanence. Ce rapport de pouvoir inégalitaire relève de logiques héritées de l'histoire du cinéma français et de sa politique des auteurs construisant le réalisateur comme « créateur » (Sellier

«Sur un plateau, oui, il faut faire gaffe. En France, le culte du réal' ou de la réal' est tellement... fort : il y a vraiment cette croyance que, sur un plateau, tout le monde doit parler à une seule personne. Je ne sais pas d'où ça sort, je pense que c'est débile. [...] C'est juste que, depuis Truffaut et Godard, les réal' ont réussi à ramasser toute la mise. " (Clément, 37 ans, collectif 1.)

Les rapports de pouvoir, au niveau économique et artistique, dans le processus de création audiovisuelle sont donc plutôt défavorables aux scénaristes, qui restent dans «l'ombre » (Aude, 43 ans, collectif 1). Constat dénoncé par nos enquêté e.s qui se mobilisent, précisément, et grâce au collectif, pour lutter contre cet which has major economic implications in a profession where unemployment insurance does not exist as writers do not fall under the French intermittent du spectacle status granted to other artists. Screenwriters are therefore professionally and economically dependent on producers. Television exhibits the same embedding of economy and creation that exists in the art world (Menger 2002).

The relationship to directors is characterized by a loss of artistic power for the screenwriter once the script has been completed. Even when they have access to film sets, screenwriters struggle to find their place there. As Margaux (44 years old, collective 1) notes, they are not given a space of their own, which gives them the feeling that they are constantly in the way on set. This inegalitarian power dynamic reflects rationales inherited from the history of French film and the impact of auteur theory, which constructed the director as a "creator" (Sellier 2004):

"On a set, yeah, you have to be careful. In France, directors are worshipped to such a degree that there's this strong belief that on a set, everyone has to talk to the same person; I don't know where that comes from, I think it's dumb. [...] So the thing is, it's just that since Truffaut and Godard, the directors have had it all." (Clément, 37 years old, collective 1.)

In the audio-visual creation process, economic and artistic power relations tend not be in the screenwriters' advantage; they tend to languish in the "shadows" (Aude, 43 years old, collective 1). Our interviewees denounce this state of affairs, and precisely mobilize against it with the help of the collective. 
À côté des rapports de pouvoir avec les producteur.rice's et les réalisateur-rice.s, on observe une diversité des rôles occupés par les scénaristes : membre d'une équipe, dialoguiste, directeur-rice de collection de séries, auteur.rice dans un atelier d'écriture, showrunner. Ces positions confèrent à chacun'e une autonomie plus ou moins forte et reflètent la division du travail entre scénaristes. Lena raconte ainsi comment une série à laquelle elle participe repose sur deux équipes : la «ligue 1 » des scénaristes réguliers et expérimentés et la « ligue 2 » des scénaristes plus jeunes, qui interviennent en complément de la ligue 1, dont les scénarios sont moins souvent retenus par la chaîne et dont la rémunération est inférieure. On retrouve ici une logique organisationnelle fondée sur une différenciation par lignes hiérarchisées de spécialités professionnelles (Menger 2002). La position dans le milieu des scénaristes influe sur les rapports avec les autres professionnel-le.s : plus un individu occupe une position élevée comme scénariste (directeur-rice de collection ou showrunner), plus il/elle acquiert de poids dans les négociations avec les producteur.rice.s et les réalisateur.rice·s.

Enfin, ces rapports de pouvoir sont aussi le fait de rapports sociaux de genre et d'âge défavorables aux femmes, notamment jeunes. Certaines pratiques professionnelles en témoignent, comme le fait de leur adjoindre des auteurs masculins, plus âgés, pour écrire les épisodes d'une série sur laquelle elles sont déjà engagées. Cette logique place alors les jeunes autrices dans des positions subalternes. Les relations de coopération qui entourent la création artistique (Becker 1988) sont, ici, doublées de présupposés sexistes (Bielby \& Bielby 2002), de hiérarchies et de formes de paternalisme qui subsistent à l'encontre des femmes, notamment les plus jeunes. Ainsi, l'idée selon laquelle les femmes sont plus organisées et seraient mieux armées pour les tâches liées à l'organisation de la production ou au management que pour les tâches créatives
Screenwriters also play a variety of roles: they may be simple team members, dialogue writers, series directors, authors in a writing workshop, or showrunners. These positions confer varying degrees of autonomy, and reflect the division of labour between screenwriters. Lena for instance told us that a series on which she writes functions with two teams: the "premier league" of regular, experienced screenwriters and the "second division" of young writers, who complement the premier league's work - the latter's scripts are less often picked by the channel and they are paid less. The organizational logic at work here rests on a differentiation based on hierarchized lines of professional specialty (Menger 2002). One's position in the milieu of screenwriters influences relationships with other professionals: the higher the individual's position as a screenwriter (series director or showrunner), the more he or she weighs in on negotiations with producers and directors.

Lastly, these power relations are also the result of gender and age relations that work to women's detriment-especially when they are young. Some professional practices reflect this: for instance, older, male writers may be assigned to work with them on episodes of a series after they have been hired, which places them in an inferior position. Here, the relations of cooperation that characterize artistic creation (Becker 1982) are marred by sexist assumptions (Bielby \& Bielby 2002), hierarchies, and forms of paternalism against women and young women in particular. Thus, the idea that women are better organized and thus better suited for organizational production or management tasks than for creative tasks dominates in the cultural industries (Hesmondhalgh \& Baker 
domine dans les industries culturelles (Hesmondhalgh \& Baker 2015) et revient implicitement dans les discours des scénaristes, à l'instar d'Élise qui déteste être prise pour « la secrétaire »:

"On me choisit en disant "bon, les garçons ont besoin d'être cadrés", toi t'es une fille et t'es sérieuse, t'es une fille, tu vas bien prendre les notes, tu vois. » (31 ans, collectifs 2 et 3.)

Sexisme et paternalisme se combinent ainsi volontiers et monter en grade, se faire un nom dans le milieu permettent aux femmes de modifier leur positionnement dans des rapports de force initialement en leur défaveur.

\subsection{La conquête de l'autonomie individuelle par le collectif}

Affinant leurs compétences, s'améliorant grâce au collectif, les auteur-rice-s gagnent en prestige et abandonnent certaines activités (Hughes 1959), par exemple l'écriture de séries industrielles et en viennent alors à refuser ou quitter les projets qui ne leur conviennent pas. Le collectif est, également, un lieu de sociabilité dans lequel se créent des «liens forts 》 (Granovetter 1973), Clément allant jusqu'à parler de «vraie famille de travail ». La force de ces relations traduit le soutien que constituent ces collectifs, comme pour Bastien qui nous dit : « S'il y avait pas eu le [collectif], je pense que j'aurais arrêté ce métier. »Cette sociabilité apporte aux individus un espace de confiance pour parler des difficultés de leur situation et se protéger d'un milieu professionnel « compétitif » et « dur » (Aude, 43 ans, collectif 1). Le collectif est souvent décrit comme un "sas de décompression ", au sein duquel les membres peuvent se plaindre, critiquer le milieu, partager leurs frustrations quotidiennes. Le groupe joue alors le rôle d'exutoire pour ses membres et leur permet de s'armer face aux professionnel.le.s qui les entourent, tout en gagnant en autonomie sur le plan artistique.
2015), and transpires in screenwriters' discourse, as in the case of Élise who hates being treated as "the secretary":

"The thing is, I'm being picked but I'm being told 'OK, the boys need monitoring,' you're a girl and you're serious, you're a girl, you'll be taking notes well, you see." (31 years old, collectives 2 and 3 .)

Sexism and paternalism routinely mix, and getting ahead, making a name for oneself allows women to change their position in power relations that initially work to their disadvantage.

\subsection{Conquering Individual Autonomy through the Collective}

Screenwriters sharpen their craft, improve thanks to the collective, and as they earn prestige, they abandon some activities (Hughes 1959), such as the writing of industrial series, and they come to turn down or leave projects that do not suit them. The collective is also a social venue in which "strong ties" are forged (Granovetter 1973); Clément even speaks of a "work family". The strength of these relationships reflects the supportive role played by the collectives, as evidenced by Bastien, who told us: "If not for the [collective], I think I'd have quit this job". This sociability gives individuals a safe space to talk about the difficulties inherent in their situation and protect themselves from a "competitive," "tough" professional environment (Aude, 43 years old, collective 1). The collective is often described as a place to "decompress," where members can complain, criticize the professional world, and share their everyday frustrations. In the group, members let off steam and arm themselves against other professionals, and in the process gain artistic autonomy. 


\subsection{Labellisation, réseaux et réputations}

Le collectif fournit enfin un réseau qui offre des opportunités de travail. Les membres travaillent ensemble, et celles et ceux qui développent leurs propres projets font appel à des collègues pour co-écrire. Une des séries actuelles à fort succès est ainsi identifiée

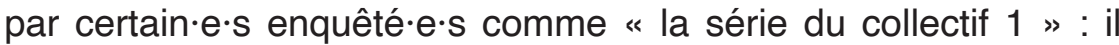
serait impossible d'y travailler en étant extérieur à ce collectif. Cet endorecrutement permet de s'imposer collectivement dans le milieu, mais crée également des mécanismes de sélection et d'exclusion. Une série d'Arte a ainsi été écrite par la moitié des membres d'un même collectif. Cela illustre la capacité des groupes à fournir, comme le disent très clairement leurs membres, du travail. Surtout, cette logique aboutit à des effets de reconnaissance forts : le collectif est progressivement identifié, dans le monde de la télévision, comme une garantie de qualité :

« Les gens ont commencé à entendre parler de nous, des fois mon agent me disait : "Ah non mais là, j'ai des gens qui me disent 'je veux du [collectif 1]' [rires] - vraiment c'est super, les producteurs disent : 'On veut du [collectif 1]'”. J'étais là... [rires] - je n'y croyais pas trop, c'était gentil de sa part, mais effectivement, il y a eu des gens qui sont venus me voir en me disant ben... » (Clément, 37 ans, collectif 1).

Jérôme (42 ans, collectif 1 ) explique que le collectif devient une sorte de "label ». Chaque membre bénéficie d'externalités positives de la part du collectif en termes de réputation : le fait d'être labellisé en ces termes lui ouvre des opportunités et renforce sa position face aux producteur.ices qui le démarchent pour cette raison. Le collectif offre alors, dans ce milieu professionnel, un nouveau mécanisme d'appariement entre les scénaristes et les producteur-ices. Ces effets de réputation sont validés par

\subsection{Labelling, Networks and Reputations}

Lastly, collectives also function as networks that offer work opportunities. Members work together, and those who develop their own projects call on others to co-write. A currently highly successful show is identified by some interviewees as "the collective 1 series": it is reportedly impossible to work on that series outside of the collective. This recruitment within collectives allows some to collectively find a footing in the profession, but it also creates mechanisms of selection and exclusion. For instance, one Arte series was written by half of the members of the same collective. This illustrates the capacity of groups to provide work, as their members very openly confirm. Most importantly, this has significant effects in terms of recognition - this particular collective has been gradually identified in televison circles as a token of quality:

"People have actually started to hear about us, sometimes my agent would go: 'Hey, you know, here I have people telling me, I want someone from [collective 1]' [laughs]-it's really great, producers say: We're looking for someone from [collective 1].' And I was like... [laughs] I didn't really believe it; it was nice of him to say, but since then I've actually had people come to me and say that..." (Clément, 37 years old, collective 1.)

Jérôme (42 years old, collective 1) explains that the collective is becoming a "label" of sorts. Each member benefits from positive externalities in terms of reputation: being labelled like this gives them opportunities and reinforces their position towards the producers who seek them out on that basis. Within the professional milieu, the collective forms a new mechanism for pairing up screenwriters with producers. These reputational effects are validated by the draw of the collective for screenwriters who are not part of it. 
l'attractivité que peut exercer le collectif sur les scénaristes qui n'en font pas partie. Antoine (41 ans, collectif 1 ) raconte ainsi comment il a voulu intégrer le collectif, attiré par le « prestige » du groupe, souhaitant stratégiquement, à titre individuel, bénéficier des effets positifs de la réputation du collectif, effets d'autant plus importants

pour pallier l'incertitude et la forte concurrence du milieu.

Le premier collectif bénéficie d'une image particulièrement prestigieuse dans le milieu. Quand on interroge nos enquêté $\cdot e \cdot s$ sur l'image de ce groupe, le vocabulaire qui en émerge est significatif : «En plus ils étaient tous beaux, bien habillés [...] C'est "prestige" [rires] - ils ont la classe, quand même [...] ; ils ont une tête à être dans les magazines » (Sabine, collectif 2), tandis que pour Élise : «Pour moi, le [collectif 2 et 3], c'est les Mad Men. Non mais c'est vrai : ils sont tous grands, super beaux, super grands, ils sont tous très cohérents. " On peut noter que ce collectif est le seul à notre connaissance à avoir bénéficié d'une médiatisation, notamment d'une double page avec photo des membres, dans un magazine. De leur côté, les membres évoquent des rumeurs d'une " aristocratie du scénario », d'une "franc-maçonnerie du scénario français ", d'une forme de "snobisme », ou encore celle selon laquelle le groupe aurait réalisé une «OPA sur les séries». De l'intérieur, la crainte est d'être percu·e.s comme « un club d'influence », ce qui est refusé par les membres du collectif ; de l'extérieur (depuis d'autres groupes), ce sont les «paillettes », le prestige et les « stars » qui sont mises en avant.

\section{Conclusion}

Les membres des collectifs décrivent ces organisations comme des supports dans des industries culturelles où le travail créatif, en particulier, est caractérisé par sa précarité, son irrégularité, ses contrats courts et l'inégalité de la rémunération, notamment (Banks
Antoine (41 years old, collective 1 ) says that he wanted to join the collective because he was drawn by the group's "prestige," and from a strategic perspective, he was individually eager to benefit from the positive effects of the collective's reputation, as those are significantly helpful in making up for uncertainty and heightened competition in the profession.

The first collective has a particularly prestigious image in the profession. When asked about that group's image, our interviewees' language is telling: "Also, they were all handsome, well dressed. [...] It's "prestige" [laughs] they're classy, you know [...]; they look like they could be in magazines" (Sabine, collective 2); "to me [in collective 2 and 3], they're the Mad Men. They really are, you know, they're all tall, super handsome, super tall, they all make sense together" (Élise). It is worth noting that, to our knowledge, that collective is the only one that has received any media coverage, including a two-page magazine article featuring a photograph of its members. For their part, members speak of rumours about an "aristocracy of screenwriting," or a "Freemasonry of French screenwriting," a kind of "snobbery," and accusations about that group "taking over series". From the inside, members express fears about being perceived as an "elite club"; from the outside (i.e., from other groups), "glitter," prestige and "stars" are highlighted.

\section{Conclusion}

Screenwriters' collectives are described by their members as support groups, in cultural industries where creative work is particularly characterized by precariousness, irregularity, short-term contracts and pay inequalities (Banks \& Hesmondhalgh 2009). Founding 
\& Hesmondhalgh 2009). La fondation et la participation à des collectifs constituent une réponse à l'individualisation marquée de ce travail, dans des industries qui vantent les vertus de l'autonomie, de l'unicité du talent et encouragent l'individualisation des pratiques professionnelles (Banks \& Hesmondhalgh 2009 : 419).

Les collectifs de scénaristes qui se développent en France depuis une douzaine d'années peuvent ainsi être un moyen pour les auteur.rice-s de lutter, à leur entrée dans le métier, contre la précarité et la solitude, par la construction de réseaux de solidarité doublés de liens d'amitié grâce auxquels évoluer, ensuite, dans les mondes de l'audiovisuel. Ce compagnonnage a également permis à ces auteur.rice's de pallier l'absence longtemps criante de formations reconnues et institutionnalisées au métier de scénariste ${ }^{16}$. Les collectifs participent donc à une redéfinition des pratiques et de l'identité professionnelle des scénaristes qui y participent, axées sur une logique coopérative d'amélioration collective des compétences et de renversement des rapports de pouvoir. Ces équipes dessinent alors une pratique propre à une génération de scénaristes soucieuse à la fois de la qualité des séries françaises et de la reconnaissance du métier

Enfin, un usage plus stratégique de ces groupes semble se faire jour, lié à la fois à leur médiatisation progressive (articles dans Télérama, Le Figaro ou encore L'Express) et au succès des séries auquel leurs membres collaborent. Ces collectifs participent à donner une visibilité aux scénaristes qui les peuplent mais aussi à redonner du lustre à une profession en conquête d'autonomie, de reconnaissance, de liberté et de pouvoir artistiques. II conviendrait toutefois de s'interroger sur la persistance de pratiques individuelles

16. La formation continue des auteur.rice-s ne leur est reconnue que depuis 2012 (source SACD, « Le droit des auteurs »). and participating in collectives is a response to the heightened individualization of this work, in industries that sing the praises of autonomy and individual talent and encourage increasingly individual professional practices (Banks \& Hesmondhalgh 2009: 419).

In France, the collectives that have emerged over the past twelve years or so may be means for new authors to combat precariousness and solitude, by building networks of solidarity that are bolstered by friendships, thanks to which they are then able to get ahead in the audio-visual worlds. This companionship has also allowed these authors to make up for the long, glaring absence of recognized, institutionalized training for the job of screenwriter ${ }^{16}$. Collectives thus contribute to redefining the practices and professional identity of participating screenwriters, drawing on a cooperative effort to collectively improve their skills and reverse power relations. They are outlets for the practices of a new generation of screenwriter, who are invested both in the quality of French series and in the recognition of their profession.

Lastly, a more strategic use of these groups appears to have emerged, owing both to their gradually increasing media exposure (with pieces in Télérama, Le Figaro and L'Express ${ }^{17}$ ) and to the success of the series on which their members work. These collectives help give exposure to their members but also restore the prestige of a profession that is looking to conquer autonomy, recognition, artistic freedom, and power. However, the persistence

16. The right to lifelong training for screenwriters was only recognized in 2012 (Source: SACD, « Le droit des auteurs », last accessed on 28 May 2019). 17. French national magazines. 
et solitaires de l'écriture de scénarios. Si les nouveaux et nouvelles entrant·e·s, récemment diplômé·e·s, tendent à intégrer ou à créer des collectifs, ceux-ci pourraient-ils devenir une nouvelle norme du métier de scénaristes qui consacrerait les pratiques et identités professionnelles défendues par nos enquêté·e·s ?

Anne-Sophie Béliard

Université Grenoble-Alpes, Laboratoire Pacte (Régulations)

Sarah Lécossais

Université Paris 13, Laboratoire des Sciences de l'information et de la

communication ( $\underline{\mathrm{LabSIC}})$ of individual and solitary practices in screenwriting also deserves investigation at a time when writers' workshops and international productions are increasingly in fashion, encouraging collaborative work. If recent graduates tend to join or create collectives, could these collectives become a new norm in the profession, resulting in the consecration of the professional practices and identities defended by our interviewees?

Anne-Sophie Béliard Université Grenoble-Alpes, Laboratoire Pacte (Régulations)

Sarah Lécossais Université Paris 13, Laboratoire des Sciences de l'information et de la communication (LabSIC) 


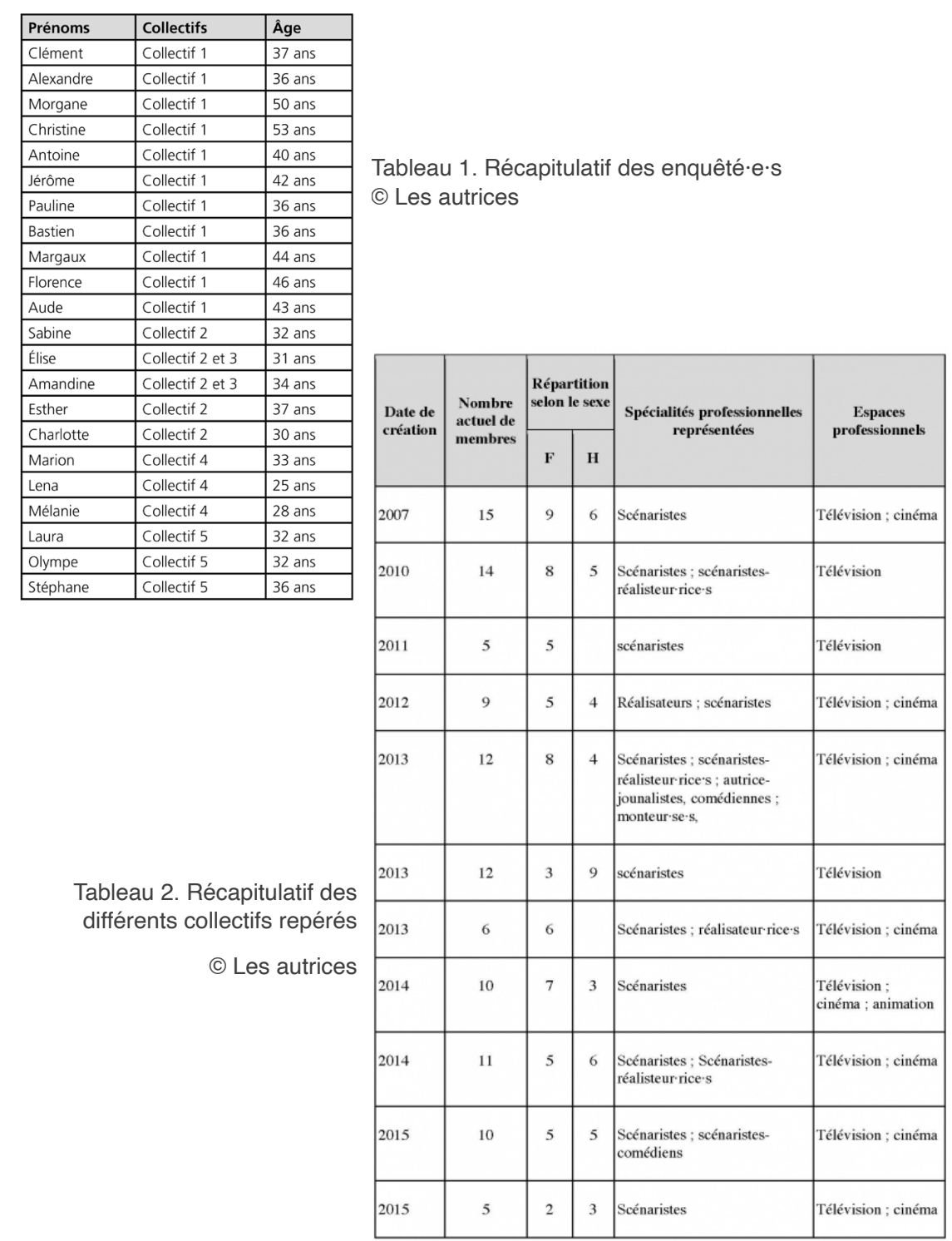

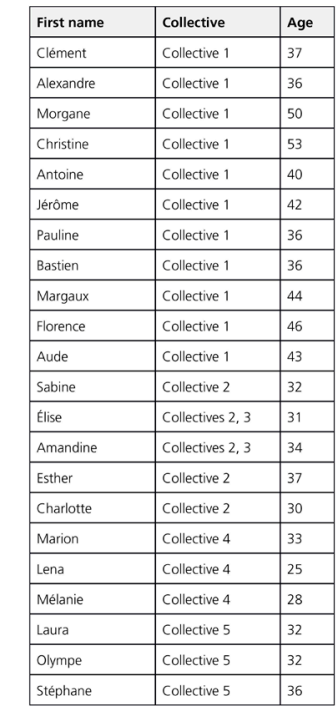

Table 2. List of collectives under study

(c) The authors

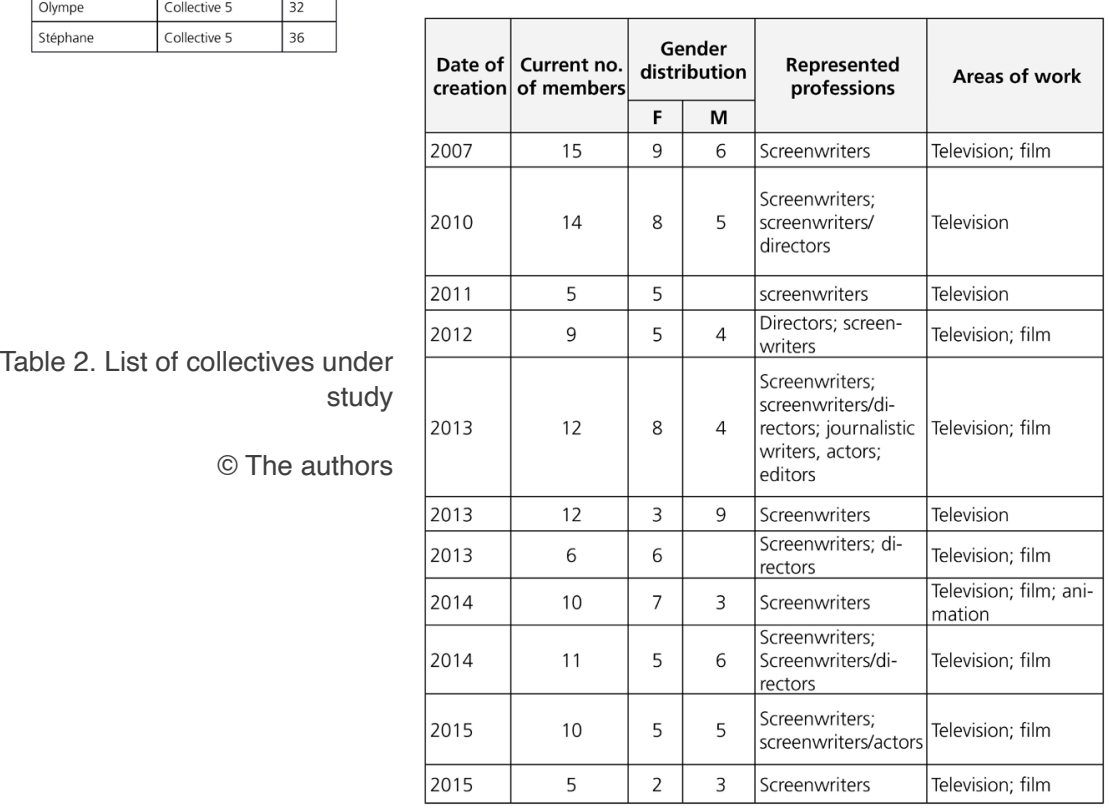

Table1. List of interviewees

(c) The authors 


\section{Références bibliographiques}

BANKS Mark \& HeSmondhalgh David (2009). « Looking for Work in Creative Industries Policy ». International Journal of Cultural Policy. 15(4) : 415430.

BANKS Miranda \& HeSmondhalgh David (2016). « Internationalizing Labor Activism. Building Solidarity among Writer's Guilds ». In CURTIN Michael \& SANSON Kevin (dir.), Precarious Creativity. Global Media, Local Labor Oakland, University of California Press : 267-280.

BAXANDALL Michael (1985) [1972]. L'CEil du Quattrocento. L'usage de la peinture dans l'Italie de la Renaissance. Traduit de l'anglais par Yvette Delsaut. Paris, Gallimard.

BECKER Howard (1988) [1982]. Les Mondes de l'art. Traduit de l'anglais par Jeanne Bouniort. Paris, Flammarion.

BIDART Claire (1997). «"Qui se ressemble s'assemble" ? . In BIDART Claire (dir.), L’Amitié, un lien social. Paris, La Découverte : 41-51.

Bielby Denise \& Bielby William T. (2002). « Hollywood Dreams, Harsh Realities : Writing for Film and Television ». Contexts, $4:$ 21-27.

CARDON Vincent \& PILMIS Olivier (2013). « Des projets à la carrière. Les artistes interprètes et leurs anticipations des contreparties du travail, une perspective biographique ». Sociétés contemporaines, 91 : 43-65.

Chalvon-Demersay Sabine (2011). « Enquête sur l'étrange nature du héros de série télévisée ». Réseaux, 165 : 181-214.

Chalvon-Demersay Sabine \& PAsquier Dominique (1990). Drôles de stars. La télévision des animateurs. Paris, Aubier.

CHIAPELLO Ève (1998). Artistes versus managers. Le management culturel face à la critique artiste. Paris, Métailié.

CSA (Rapport) (2010). Pour une relance de la fiction française. Étude réalisée par la société SESPA. [En ligne] [consulté le 08/03/2019].

\section{References}

Banks Mark \& HesmondHALGH David (2009). "Looking for Work in Creative Industries Policy." International Journal of Cultural Policy. 15(4) : 415-430.

BANKs Miranda \& HeSMONDHALGH David (2016). "Internationalizing Labor Activism. Building Solidarity among Writer's Guilds." In CURTIN Michael \& SAnson Kevin (eds.), Precarious Creativity. Global Media, Local Labor. Oakland, University of California Press : 267-280.

BaXANDALl Michael (1972). Painting and Experience in 15th Century Italy. Oxford, Oxford University Press

BECKER Howard (1982). Art Worlds. Berkeley, University of California Press.

BIDART Claire (1997). "'Qui se ressemble s'assemble'?.” In BIDART Claire (eds.), L’Amitié, un lien social. Paris, La Découverte : 41-51.

Bielby Denise \& Bielby William T. (2002). "Hollywood Dreams, Harsh Realities : Writing for Film and Television". Contexts, 4 : 21-27.

CARdon Vincent \& PILMIS Olivier (2013). "Des projets à la carrière. Les artistes interprètes et leurs anticipations des contreparties du travail, une perspective biographique." Sociétés contemporaines, 91 : 43-65.

ChaLVON-DemERSAY Sabine (2011). "Enquête sur l'étrange nature du héros de série télévisée." Réseaux, 165 : 181-214.

Chalvon-Demersay Sabine \& Pasquier Dominique (1990). Drôles de stars. La télévision des animateurs. Paris, Aubier.

CHIAPELLo Ève (1998). Artistes versus managers. Le management culture face à la critique artiste. Paris, Métailié.

CSA (Rapport) (2010). Pour une relance de la fiction francaise. Étude réalisée par la société SESPA. [En ligne] [consulté le 08/03/2019].

Edgerton Gary \& Jones Jeffrey P. (eds.) (2008). The Essential HBO Reader. Lexington, The University Press of Kentucky. 
Edgerton Gary \& Jones Jeffrey P. (dir.) (2008). The Essential HBO Reader. Lexington, The University Press of Kentucky.

Freidson Eliott, Chamboredon Jean-Claude, Menger Pierre-Michel (1986). "Les professions artistiques comme défi à l'analyse sociologique ". Revue française de sociologie, 27(3) : 431-443.

GouYon Marie (2011). " Diversité des carrières d'auteur de l'audiovisuel et du spectacle vivant. Les auteurs de la SACD, 1997-2008 ». Rapport. Culture chiffres, 2 : 1-32.

GranovetTer Mark (2000) [1973]. « La force des liens faibles ». In Le Marché autrement, traduit de l'anglais par Isabelle This-Saint-Jean. Paris, Desclée de Brouwer : 45-74.

GregolRe Mathieu (2009). " La clôture comme seule protection ? Syndicats du spectacle et marché du travail dans l'entre-deux-guerres (1919-1937) ». Sociologie du travail, 51(1) : 1-24.

HEINICH Nathalie (1993). Du peintre à l'artiste : artisans et académiciens à l'âge classique. Paris, Minuit.

HéRAN François (1990). "Trouver à qui parler : le sexe et l'âge de nos interlocuteurs ». Données sociales, Paris, INSEE : 364-368.

HesmondHALGH David (2007). The Cultural Industries. Londres, Sage.

HesmondHALGH David \& BAKER Sarah (2015). « Sex, Gender and Work Segregation in the Cultural Industries ». The Sociological Review, 63(1) : 23-36.

HugHES Everett C. (1959). «Prestige ». Annals of the American Academy of Political and Social Science, 325 : 45-49.

McCABE Janet \& AKASS Kim (dir.) (2007). Quality TV : Contemporary American Television and Beyond. Londres, I. B. Tauris.

MENGER Pierre-Michel (1991). « Marché du travail artistique et socialisation du risque : le cas des arts du spectacle ». Revue française de sociologie, $32(1): 61-74$
Freidson Eliott, Chamboredon Jean-Claude, Menger Pierre-Michel (1986). "Les professions artistiques comme défi à l'analyse sociologique." Revue française de sociologie, 27(3) : 431-443.

GouYon Marie (2011). "Diversité des carrières d'auteur de l'audiovisue et du spectacle vivant. Les auteurs de la SACD, 1997-2008." Rapport. Culture chiffres, $2: 1-32$.

GranovetTer Mark (1973). "The Strength of Weak Ties." The American Journal of Sociology, 78(6) : 1360-1380.

GREGOIRE Mathieu (2009). "La clôture comme seule protection? Syndicats du spectacle et marché du travail dans l'entre-deux-guerres (1919-1937)." Sociologie du travail, 51(1) : 1-24.

HEINICH Nathalie (1993). Du peintre à l'artiste : artisans et académiciens à l'âge classique. Paris, Minuit.

Héran François (1990). "Trouver à qui parler : le sexe et l'âge de nos interlocuteurs." Données sociales, Paris, INSEE : 364-368.

Hesmondhalgh David (2007). The Cultural Industries. Londres, Sage.

HesmondHalgh David \& BakeR Sarah (2015). "Sex, Gender and Work Segregation in the Cultural Industries." The Sociological Review, 63(1) : 23-36.

HuGHes Everett C. (1959). "Prestige." Annals of the American Academy of Political and Social Science, 325 : 45-49.

McCABE Janet \& AKASS Kim (eds.) (2007). Quality TV : Contemporary American Television and Beyond. Londres, I. B. Tauris.

MeNGeR Pierre-Michel (1991). "Marché du travail artistique et socialisation du risque : le cas des arts du spectacle." Revue française de sociologie, 32(1) : 61-74.

MeNGeR Pierre-Michel (2002). Portrait de l'artiste en travailleur. Métamorphoses du capitalisme. Paris, Seuil.

Mille Muriel (2018). '“Chaque mot a un coût.' Les contraintes de la fabrication d'un feuilleton télévisé." Savoir/Agir, 44 : 55-64. 
Menger Pierre-Michel (2002). Portrait de l'artiste en travailleur. Métamorphoses du capitalisme. Paris, Seuil.

MiLle Muriel (2018). " "Chaque mot a un coût". Les contraintes de la fabrication d'un feuilleton télévisé ». Savoir/Agir, 44 : 55-64.

NAUDIER Delphine (2013). " La construction sociale d'un territoire professionnel : les agents artistiques ». Le Mouvement social, $243: 41$ 51.

PASqUIER Dominique (1995). Les Scénaristes et la télévision. Approche sociologique. Paris, Nathan/INA.

SELLIER Geneviève (2004). « Le cinéma d'auteur-e français, ou l'intime comme évitement du social ». In SelLIER Geneviève \& VIENNOT Éliane, Culture d'élite, culture de masse et différence des sexes. Paris, L'Harmattan : 105-121.

SofIO Séverine (2007). « Des discours aux pratiques, comment approcher la réalité des rapports de sexe ? Genre et professions artistiques au XIXe siècle ». Sociétés \& Représentations, 24 : 177-193.

WREYFORD Nathalie (2015). «Birds of Feather : Informal Recruitment Practices and Gendered Outcomes for Screenwriting Work in the UK Film Industry ». The Sociological Review, 63 : 84-96.
NAUDIER Delphine (2013). "La construction sociale d'un territoire professionnel : les agents artistiques." Le Mouvement social, 243 : 41-51.

PASQUIER Dominique (1995). Les Scénaristes et la télévision. Approche sociologique. Paris, Nathan/INA.

SelLIER Geneviève (2004). "Le cinéma d'auteur-e français, ou l'intime comme évitement du social." In SELLIER Geneviève \& VIENNOT Éliane, Culture d'élite, culture de masse et différence des sexes. Paris, L'Harmattan : 105-121.

SofIo Séverine (2007). "Des discours aux pratiques, comment approcher la réalité des rapports de sexe? Genre et professions artistiques au XIX ${ }^{e}$ siècle." Sociétés \& Représentations, 24 : 177-193.

WREYFORD Nathalie (2015). "Birds of Feather : Informal Recruitment Practices and Gendered Outcomes for Screenwriting Work in the UK Film Industry." The Sociological Review, 63 : 84-96. 